\title{
Perancangan Sistem Wahana Perkemahan Ramah dan Aman Sebagai Daya Tarik Wisatawan Bumi Perkemahan Bedengan
}

\author{
Chusnana Insjaf Yogihati1 ${ }^{*}$, Markus Diantoro², Nasikhudin ${ }^{3}$, Sefia Kharen Gilar Tiana ${ }^{4}$, Akhmad Al \\ Ittikhad $^{5}$ \\ 1,2,3,4,5 Universitas Negeri Malang, Jl. Semarang 5 Malang 65145, Indonesia

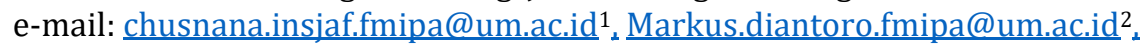 \\ $\underline{\text { nasikhudin.fmipa@um.ac.id }}^{3}{ }_{2}$ sefiakharen@gmail.com $^{4}{ }_{2} \underline{\text { ittikhad@gmail.com }}^{5}$ \\ *Penulis Korespondensi: E-mail: chusnana.insjaf.fmipa@um.ac.id
}

\begin{abstract}
The tourist area of Bumi Perkemahan Bedengan was located in Selokerto, Selorejo, Dau, Malang, East Java. It was opened in 2007 and was originally a mahogany tree nursery. The Bedengan camp area was currently a fairly educational camping area that combines elements of recreation with education or what was known as "Recreational Education". As a camping area, Bumi Perkemahan Bedengan was still not informative on the map of the camp area, and there was still a lack of directions. Visitors will certainly found a certain place if the information area was still lacking. Other problems were that the level of neatness and cleanliness was still low, where there were still many blocks of the camp area that still have dirt. There was also a lot of useless scrubs in the camping area, and there were still lots of logs scattered about. The solution was made the installation of camping that was friendly and safe as a tourist attraction and the convenience of visitors. In addition, it made the camping area more innovative as an educational camp so as to create friendly and safe "recreational education" facilities
\end{abstract}

Keywords: camp, Bedengan, safe, friendly, recreational education.

\begin{abstract}
Abstrak
Kawasan wisata Bumi Perkemahan Bedengan terletak di Dusun Selokerto, Desa Selorejo, Kecamatan Dau, Kabupaten Malang, Jawa Timur. Dibuka pada tahun 2007 dan awalnya merupakan tempat pembibitan pohon mahoni. Kawasan perkemahan Bedengan saat ini merupakan kawasan perkemahan yang cukup edukatif yang menyatukan unsur- unsur rekreasi dengan edukasi atau yang dikenal dengan "Pendidikan Rekreasi". Sebagai kawasan perkemahan, Bumi Perkemahan Bedengan masih belum informative dalam pemetaan area perkemahan, dan masih kurangnya penunjuk arah. Pengunjung tentunya akan kesulitan menemukan spot tertentu bila informasi area masih kurang. Permasalahan lainnya juga tingkat kerapian dan kebersihan juga masih rendah dimana masih banyak blok-blok area perkemahan yang masih beralasakan tanah. Banyak dijumpai juga semak- semak belukar yang tidak berguna dan tidak seharusnya ada di area untuk berkemah, serta masih ditemukan banyak tumpukan kayu yang masih berserakan. Solusi yang mampu dilakukan yaitu dengan membuat instalasi wahana perkemahan yang ramah dan aman sebagai daya tarik wisatawan dan kenyamanan para pengunjung. Selain itu menjadikan kawasan perkemahan lebih inovatif sebagai perkemahan yang edukatif sehingga terwujudnya sarana "pendidikan rekreasi" yang ramah dan aman
\end{abstract}

Kata kunci: perkemahan, Bedengan, aman, ramah, pendidikan rekreasi.

\section{PENDAHULUAN}

Bumi perkemahan Bedengan secara geografis terletak di Dusun Selokerto, Desa Selorejo, Kecamatan Dau, Kabupaten Malang, Jawa Timur. Bumi perkemahan Bedengan merupakan salah satu bagian dari kawasan wisata Bedengan. Kawasan wisata Bedengan berjarak kurang lebih 25 km dari pusat kota Malang. Kawasan wisata Bedengan memiliki luas 13,7 Ha, sedangkan kawasan perkemahannya memiliki luas 2,5 Ha. Bedengan berada 
di kawasan yang memiliki topografi berbukit- bukit. Status kepemilikan Bedengan dimiliki dan dikelola oleh Perhutani. Sementara itu pengolaha hariannya dilakukan oleh Lembaga Kemitraan Desa Pengolah Hutan (LKDPH) Desa Selorejo. LKDPH merupakan lembaga yang berada di bawah Kesatuan Pemangku Hutan (KPH) Kabupaten Malang (Sutadji, Nurmalasari, \& Nafiah, 2020).

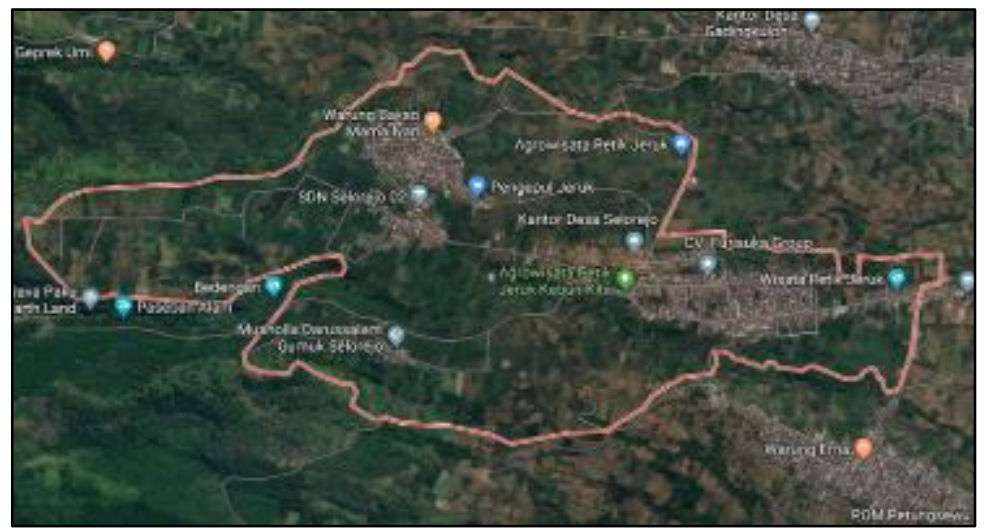

Gambar 1. Peta Satelit Desa Selorejo

(Sumber : Google Maps)

Desa Selorejo yang merupakan kawasan dataran tinggi, menjadikannya kawasan wisata yang sejuk dan asri. Pangunjung yang datang akan disuguhi pemandangan alam yang indah dan udara yang dingin. Memasuki kawasan wisata Bedengan, pengunjung akan disambut pepohonan pinus. Kawasan wisata Bedengan memiliki akses jalan yang sudah bagus, sebab akses jalannnya telah diperbaiki dari yang sebelumnya jalanan sangat sulit dilalui karena becek pada saat musim hujan. Kawasan wisata Bedengan dibuka pada tahun 2007 dan awalnya merupakan tempat pembibitan pohon mahoni ("Wahana Alam Bedengan," 2014). Hingga akhirnya berkembang menjadi kawasan wisata Bedengan yang menyuguhkan pemandangan alam yang asri dan dijadikannya sebagai kawasan perkemahan (Pertiwi, 2017). Sebagai kawasan perkemahan, Bumi Pekemahan Bedengan menjadi tempat yang ideal sebab lokasiya yang berdekatan dengan sumber air bersih.karena adanya sungai. Sungai kecil disekitar perkemahan menjadikannya nilai plus tersediri bagi bumi perkemahan ini yang banyak memikat para pengunjuang (Sutadji et al., 2020).

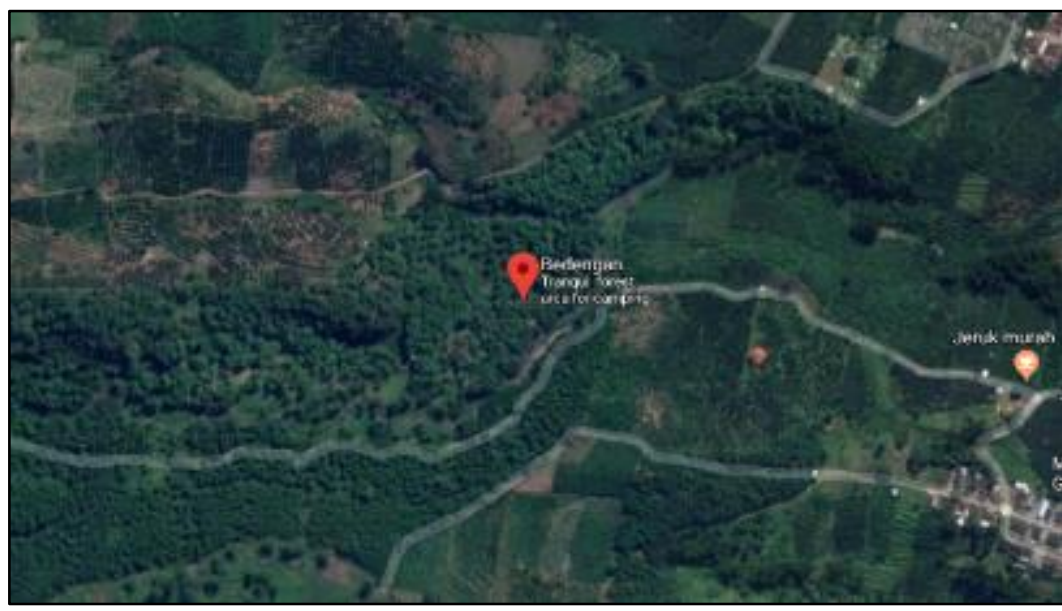

Gambar 2. Kawasan Bumi Perkemahan Bedengan

(Sumber : Google Maps) 
Kawasan perkemahan Bedengan saat ini hanya sebagai kawasan perkemahan yang cukup edukatif yang menyatukan unsur- unsur rekreasi dengan edukasi atau yang dikenal dengan "Pendidikan Rekreasi" (Satya, 2018). Rekreasi merupakan cangkupan dari arti luas mengenai pendidikan. Suatu pandangan kontemporer, yang disampaikan oleh Hutchinson menjelaskan bahwa rekreasi merupakan bagian integral dari proses pendidikan secara keseluruhan. Pandangan semacam ini di dasarkan pada asumsi bahwa proses belajar terdiri dari komponen-komponen yang dapat diterapkan dalam berbagai situasi rekreasi. Melalui pendidikan rekreasi, prinsip- prinsip pendidikan aktual dapat diterapakan yang meliputi motivasi, pemahaman, prestasi, dan transfer belajar melalui situasi lainnya oleh karena itu rekreasi merupakan wadah untuk mencapai tujuan pendidikan (Iva, 2013). Melalui potensi yang ada di kawasan rekreasi, maka kegiatan yang ada di dalamnya dapat digunakan sebagai sarana mengisi waktu luang dengan kegiatan yang positif yang mengarah pada kegiatan edukasi. Kawasan bumi perkemahan Bedengan akan lebih berpotensi sebagai sarana pendidikan rekreasi apabila fasilitas yang ada pada tempat wisata bumi perkemahan Bedengan menunjang tujuan tersebut (Raksun \& Karnan, 2019).

Di bumi perkemahan Bedengan, tingkat kerapian dan kebersihan juga masih rendah dimana masih banyak blok- blok area perkemahan yang masih beralasakan tanah. Banyak dijumpai juga semak- semak belukar yang tidak berguna dan tidak seharusnya ada di area untuk berkemah, serta masih ditemukan banyak tumpukan kayu yang masih berserakan (Pertiwi, 2017). Kondisi tersebut dapat berdampak pada keselamatan para pengunjung yang menginap di lokasi perkemahan sebab akan menjadi tempat untuk hewan- hewan liar berkunjung seperti ular. Kondisi buruk lainnya terjadi apabila musim hujan telah tiba, apabila hujan turun air hujan masih banyak yang menggenang disekitar tenda- tenada perkemahan. Genangan air memicu pertumbuhan nyamuk yang dapat mengganggu kenyaman pengunjung, dan lebih parahnya lagi dapat membawa penyakit deman berdarah (Prasetyo \& Yulianingsi, 2012).

Sebagai kawasan perkemahan, Bumi Perkemahan Bedengan masih belum informative dalam pemetaan area perkemahan, dan masih belum adanya penunjuk arah. Pengunjung tentunya akan kesulitan menemukan spot tertentu bila informasi area masih kurang. Permasalahan lainnya juga disebabkan kurangnya rambu penanda kondisi suatu tempat di kawasan perkemahan tersebut, hal ini dapat membahayakan pengunjung semisal pengunjung tidak mengetahui bahwa area tersebut memiliki bahaya semisal berupa lubang besar atau jurang (Nasihin, Kosasih, \& Nurlaila, 2019).

Kurangnya infrastruktur dan fasilitas di Bumi Perkemahan Bedengan menjadi masalah bagi pengunjung. Kekurangan ini bukan hanya pada kuantitas namun lebih pada kualitas. Seperti kebersihan MCK yang masih kurang adalah salah satu contohnya. Jumlah yang memadai apabila kualitasnya buruk akan berdampak buruk bagi para pengunjung. Keberadaan MCK yang bersih merupakan salah satu kebutuhan dasar bagi para pengunjung, sebab pengunjung yang berniat berkemah akan berada di temapt Bumi Perkemahan Bedengan selama jangka waktu lebih dari satu hari. Oleh karena itu fasilitas MCK perlu diperhatikan bagi dari segi kuantitas dan kualitasnya (Pertiwi, 2017; ROHMAH, 2015).

Perbaikan infrastruktur dan penambahan fasilitas yang masih kurang di kawasan perkemahan menjadi inovasi penting sebagai upaya menjadikan kawasan perkemahan ini menjadi perkemahan yang edukatif sehingga terwujudnya sarana "pendidikan rekreasi" yang ramah dan aman. Pengunjung yang datang tidak hanya akan melepas penat dan mendapat suguhan pemanangan alam yang indah, namun juga mendapatkan sinergi untuk menjadi manusia yang lebih baik lagi. Konsep-konsep baru yang mampu menunjang 
berdirinya kawasan perkemahan Bedengan yang aman, ramah, dan edukatif perlu untuk dilakukan.

\section{METODE PELAKSANAAN}

Metode pelaksanaan dibagi dalam kurun waktu 1 tahun. Berikut adalah metode pelaksanaan yang akan dilakukan:

1. Indentifikasi masalah

- Tim pengabdian, warga, dan pengolah Bumi Perkemahan Bedengan bersama-sama menemukan dan melihat ulang secara kritis potensi yang berhubungan dengan permasalahan di Bumi Perkemahan Bedengan

- Tim pengabdian, warga, dan pengolah Bumi Perkemahan Bedengan bersama-sama melakukan perencanaan waktu dan penentuan tempat yang tepat untuk pelaksanaan setiap program.

2. Analisis kebutuhan

Tim pengabdian, warga, dan pengolah Bumi Perkemahan Bedengan bersama- sama menentukan kebutuhan yang diperlukan dalam pelaksanaan program.

3. Penyusunan Program

Program yang menjadi prioritas adalah untuk:

- Menjadikan Bumi Perkemahan Bedengan sebagai wadah "Pendidikan Rekreasi"

- Program untuk mengantisipasi terdapatnya hewan liar di area perkemahan.

- Menambah dan memperbaiki fasilitas.

4. Pelaksanaan, monitoring, dan evaluasi program

5. Lokakarya Hasil dengan menghadirkan stakeholder program.

6. Pelaporan

\section{HASIL dan PEMBAHASAN}

Pada kegiatan pengabdian masyarakat ini, diimplementasikan di kawasan Bumi Perkemahan Bedengan yang berfokus pada perbaikan fasilitas area perkemahan dan pelatihan. Perbaikan area penempatan tenda menjadi fokus utama dalam pengabdian ini, dimana penempatan tenda tidak hanya beralasan tanah saja namun beralasan vaping sehingga menjadi lebih ramah dan aman untuk ditempati pengunjung yang berkemah. Pemilihan tempat disepakati bersama antara ketua penelitian dengan ketua pengelolah kawasan Bumi Perkemahan Bedengan dengan mempertimbangakan pembangun wahana lainnya dari ketua kegiatan lainnnya pula seperti yang ditunjukkan pada Gambar 3.

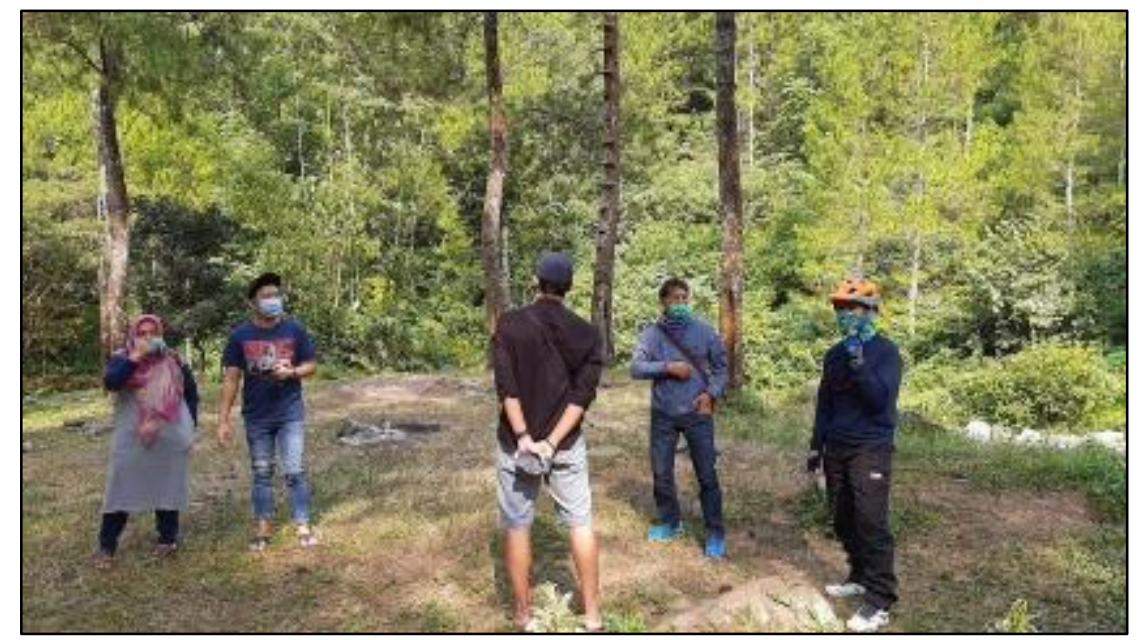

Gambar 3. Lokasi pembangungan penempatan tenda kemah 
(Sumber : Dokumentasi pribadi)

Pada tanggal 27 Agustus 2020, dilakukan proses pembangunan paving sebagai pondasi alas tenda perkemahan. Tim pengamdian turut serta dalam proses pembangunan ini yakni penyerahkan dan pengarahan desain yang diinginkan kepada Bapak Agus selaku pemimpin tim pembangunan paving perkemahan. Proses pertama dilakukan dengan meratakan tanah untuk membangun pondasi area pemavingan. Daerah yang divaping terdiri dari tiga unit yang masing-masing memiliki ukuran 4 × 2,5 m. Pondasi ditempatkan pada tanah yang tinggi, bertujuan agar mengurangi resiko terkenanya air yang diakibatkan oleh genangan air hujan, dengan demikian area perkemahan khusunya didalam tenda menjadi lebih bersih dan juga nyaman seperti ditunjukkan pada Gambar 4.

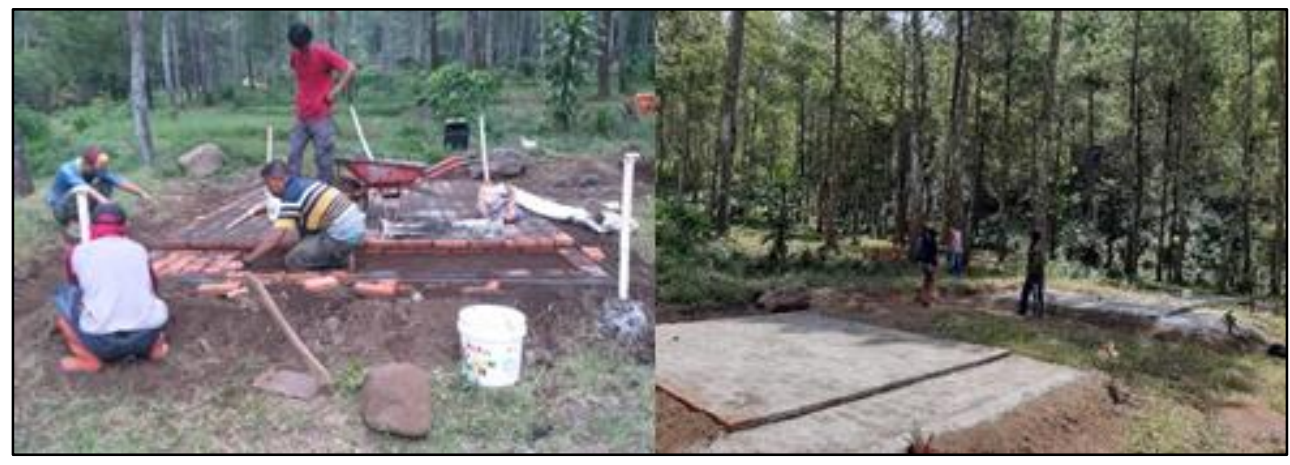

Gambar 4. Proses kontruksi pondasi area penempatan tenda

(Sumber : Dokumentasi pribadi)

Tempat pemasangan tenda perkemahan yang sudah jadi, selanjutnya tim pengabdian membeli dan memasang tenda yang sesuai dengan yang dirancang di proposal pengamdian. Tenda yang dipesan memiliki keunggulan dimana kain yang digunakan lebih tebal seperti yang ditunjukkan pada Gambar 5. Pemasangan tenda dilakukan pada tanggal 2 Oktober 2020. Pada kesempatan ini juga dilakukan uji coba oleh LP2M yang sekaligus menjadi tempat diadakanya monev.

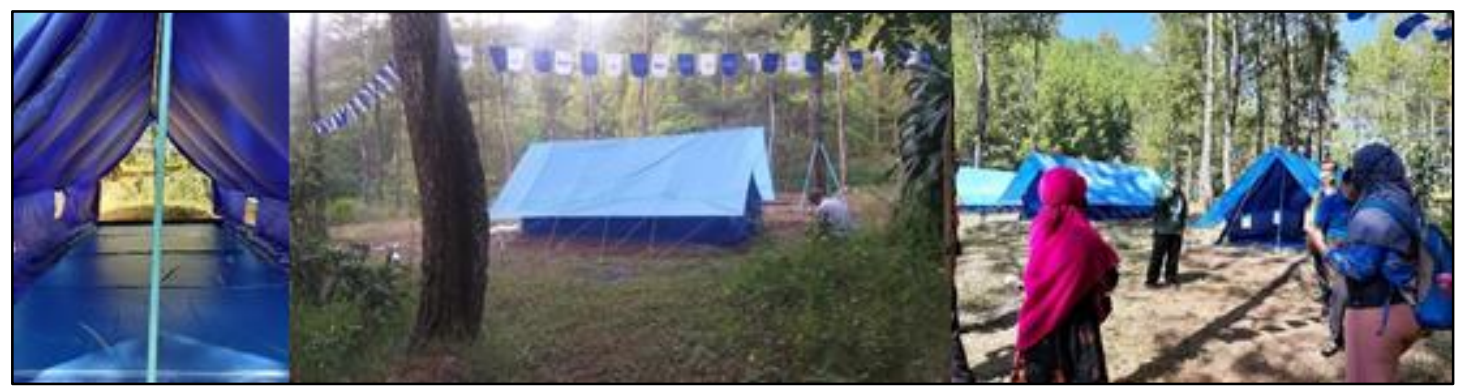

Gambar 5. Hasil pemasangan tenda perkemahan

(Sumber : Dokumentasi pribadi)

\section{KESIMPULAN}

Wahana Perkemahan yang ramah dan aman sebagai daya tarik wisatawan dan kenyamanan para pengunjung Bumi Perkemahan Bedengan. Selain itu menjadikan kawasan perkemahan lebih inovatif sebagai perkemahan yang edukatif sehingga terwujudnya sarana "pendidikan rekreasi" yang ramah dan aman.

\section{UCAPAN TERIMAKASIH}


Kami mengucapkan banyak terimakasih kepada LP2M Universitas Negeri Malang yang telah mendanai kegiatan pengabdian masyarakat ini, pemerintah Dusun Selokerto, Desa Selorejo, Kecamatan Dau, Kabupaten Malang, sebagai mitra pengabdian, dan pengurus Bumi Perkemahan Bedengan yang telah membantu dalam kegiatan pengabdian.

\section{DAFTAR PUSTAKA}

Iva, S. (2013). Managemen Pengolahan Fasilitas Outbound Objek Wisata Linggo Asri Sebagai Wahana Pendidikan Rekreasi di Kabupaten Pekalongan Tahun 2013. Semarang: Pendidikan Jasmani Kesehatan dan Rekreasi Fakultas Ilmu Keolahragaan Universitas Negeri Semarang.

Nasihin, I., Kosasih, D., \& Nurlaila, A. (2019). Peningkatan Kapasitas Media Sosial Interpretasi Bumi Perkemahan Pasir Batang Desa Karangsari Kecamatan Darma Kabupaten Kuningan, Jawa Barat, Indonesia. Empowerment: Jurnal Pengabdian Masyarakat, 2(01), 1-10. https://doi.org/10.25134/empowerment.v2i01.1786

Pertiwi, M. (2017). Bumi Perkemahan Bedengan, Cocok untuk Sarana Edukasi. Diambil dari https://www.kompasiana.com/maiayahoo/5911a5af02b0bd894f04bc96/bumiperkemahan-bedengan-cocok-untuk-sarana-edukasi?page=all/

Prasetyo, F. E., \& Yulianingsi, W. (2012). PELATIHAN TRAINER OUTBOUND DALAM MENGEMBANGKAN DESA WISATA DI DESA BAJULAN KECAMATAN LOCERET KABUPATEN NGANJUK. https://journal.unesa.ac.id/index.php/jpls/inde, 1.

Raksun, A., \& Karnan, K. (2019). Pembinaan Masyarakat dalam Budidaya Tanaman Cabai Rawit dengan Sistem Bedengan Lahan dan Aplikasi Mulsa Plastik. Jurnal Pengabdian Magister Pendidikan IPA, 1(2), 1-7. https://doi.org/10.29303/jpmpi.v1i2.240

ROHMAH, S. (2015). ANALISIS SEBARAN KESUBURAN TANAH DENGAN METODE POTENSIAL DIRI ( SELF POTENTIAL) ( Studi Kasus Daerah Pertanian Bedengan Malang) SKRIPSI Oleh : SITI ROHMAH.

Satya, B. (2018). Wisata Edukatif, Mengenal alam di Bedengan Desa Selorejo Dau Malang. Diambil dari http://arek-jagalan.blogspot.com/2018/01/wisata-edukatif-mengenalalam-di-bedengan-selorejo-dau-malang.html/

Sutadji, E., Nurmalasari, R., \& Nafiah, A. (2020). PENGEMBANGAN POTENSI WISATA KAWASAN BEDENGAN DENGAN PEMBANGUNAN FASILITAS RUMAH POHON UNTUK WISATAWAN. 1(2), 107-112.

Wahana Alam Bedengan. (2014). Diambil 10 November 2020, dari GalamedialLABS website: http://ngalam.id/read/4720/wana-wisata-alam-bedengan/ 